\title{
A review of the status of the Green Peafowl Pavo muticus and recommendations for future action
}

\author{
P. J. K. McGOWAN, J. W. DUCKWORTH, WEN XIANJI, B. VAN BALEN, \\ YANG XIAOJUN, MOHD, KHAN MOMIN KHAN, SITI HAWA YATIM, \\ LALRAM THANGA, IWAN SETIAWAN and RAHUL KAUL
}

\section{Summary}

The Green Peafowl has undergone a substantial decline throughout East Asia since the turn of the century and is now reported only from a few widely scattered localities in several countries. Its plight was highlighted in the IUCN Pheasant Action Plan where it was one of the highest priorities for conservation action. Recent surveys have clarified its status and distribution in at least part of several range countries and there is patchy information from elsewhere in its range. The current knowledge of the species was reviewed at a workshop in Malaysia in autumn 1997 at which representatives from most key countries were present. The species is extinct in Peninsular Malaysia, and almost lost from Bangladesh and north-east India. There is one large population remaining in Thailand and the species is thought to be in danger of extinction in Laos. China and Indonesia hold mostly small and scattered populations although the latter does contain two large protected populations. The status in Myanmar and Cambodia is unknown, although the presence of large tracts of apparently suitable habitat in eastern Cambodia suggest that this area may hold the largest populations of the species. Conservation recommendations fall into four categories: a strategic review, assessing status and understanding ecological requirements, investigating the human-Green Peafowl relationship and considering the possibility of reintroducing the species where appropriate.

\section{Introduction}

The Green Peafowl Pavo muticus was widely distributed in suitable habitat throughout much of eastern Asia at the turn of the century. It was found from south-east Assam (in north-east India) through Burma (now Myanmar), Thailand, Laos, Vietnam and northern Cambodia, Peninsular Malaysia and on to Java in Indonesia. It occurred in open habitats, such as sandbanks on wide meandering rivers fringed by forest and in park-like areas where long grass was dotted with trees and forest patches (Delacour 1977). It was widespread and common throughout its range 50-100 years ago, and there were no concerns about its status until recently. Beebe (1922), however, did suggest that numbers on Java were declining although it was still found throughout that island. 
The little historical information on numbers that exists is anecdotal; Beebe (1922) found and watched them with little difficulty. Detailed historical numbers were provided by van Balen et al. (1995) for Java, but they could not quantify the decrease in abundance. Evidence for a substantial decline is based, therefore, on known extinctions and the relict distribution of the remaining populations within the area from which the species was known historically.

Here we summarize recent information on wild populations of the species from both published and unpublished sources. We then propose a series of actions that would help ensure the survival of the species.

\section{Current status}

\section{Peninsular Malaysia}

The Green Peafowl is presumed extinct in Peninsular (=West) Malaysia (Davison and Scriven 1987). The only records in the early 1960s were from Kemaman and Besut in Terengannu State (Medway and Wells 1976) and extinction is thought to have followed a few years later. The species is totally protected under the Protection of Wildlife Act 1972.

\section{North-east India and Bangladesh}

There have been no systematic surveys for peafowl anywhere in north-east India or Bangladesh. The Green Peafowl may be extinct throughout north-east India where it almost certainly no longer survives in Mizoram. There are, however, reports from Manipur (Choudhury 1992, Ramanujam in McGowan and Garson 1995). There is no recent information from the remainder of its former range in Arunachal Pradesh, Nagaland and Tripura, or from Bangladesh (Harvey 1990). It is protected under the Wildlife Protection Act 1972. A single bird, supposedly brought across from Tibet, survived in captivity at the Rumtek Monastery in east Sikkim in north-east India until the early 1990s (U. Lachungpa verbally 1997).

\section{Thailand}

Human persecution has eradicated the species almost entirely from Thailand (Round 1988) and it is now thought to persist in only one location, Huai Kha Khaeng Wildlife Sanctuary, close to the Burmese border. Some 225-300 were estimated for this area by Stewart-Cox and Quinnell (1990) and Stewart-Cox (in McGowan and Garson 1995) and it has recently expanded into an adjacent valley (Stewart-Cox 1997). It is a Category One protected species in Thailand.

\section{Vietnam}

Historically, the Green Peafowl occurred throughout the country (except perhaps in the far south: Delacour 1977), but its numbers are now much reduced, mainly due to habitat loss (Nguyen $\mathrm{Cu}$ and Eames 1993). No surveys have targeted the species, but general wildlife surveys have provided information on minimum population sizes and areas occupied. It is totally protected under Government 
Decree 18 which prohibits killing, egg collection, sale of dead individuals or the keeping of dead individuals of selected species.

Since 1986 the species has been reported from seven provinces (Le Trong Trai 1997), of which five are considered to be based upon reliable fieldwork and still to have extant populations. These five provinces (Kon Tum, Dak Lak, Binh Phuoc, Dong Nai and Phu Yen) all lie in the southern third of the country; the northern two-thirds have higher human population densities with attendant higher levels of disturbance. Confirmation of survival is required from two sites: Muong Nhe National Park (Lai Chau Province, far northern Vietnam) and near Bach Ma National Park (Thua Thien Province, central Vietnam). The former is far from other known contemporary sites and the original report lacks detail. The latter record was from habitat considered marginal, where roost trees were lacking and hunting pressure was intense (Nguyen Cu verbally 1997). For these reasons it is thought that the species is unlikely to still survive in the area ( $\mathrm{J}$. Eames and Nguyen Cu verbally 1997).

The species may occur in another two provinces to the east (Khanh Hoa and Ninh Thuan) and Gia Lai, the third province on the Tay Nguyen Plateau (the others being Dak Lak and Kon Tum), as it was common there in 1979-1981 (Nguyen Cu verbally 1997). The districts of Bao Loc and Di Linh in Lam Dong Province also used to hold the species. Ho Chi Minh City Zoo claimed recently to obtain birds from this province (Nguyen $\mathrm{Cu}$ verbally 1997).

Population estimates are difficult to make, but in three parts of Dak Lak Province the species seemed distributed in areas each of about $100-200 \mathrm{~km}^{2}$ during general wildlife surveys in 1997. It avoided villages and so the area actually inhabited by peafowl is thus likely to be somewhat patchy and less than $500 \mathrm{~km}^{2}$ in total (Le Xuan Canh et al. 1997). There has clearly been a major decline in this province as during 1978-1983 the peafowl was abundant in much of the province, including some of the sites visited in 1997. It was seen in groups of up to eight, even by roads, and people often caught young birds and reared them (Nguyen Cu verbally 1997).

The only density estimate in Vietnam is that by Robson et al. (1991), who recorded up to 17 calling males in approximately $13 \mathrm{~km}^{2}$ in the centre, south-east and north-east of Cat Tien National Park in Dong Nai Province.

\section{Laos}

The species was originally common and widespread throughout Laos (e.g. Delacour 1929, Engelbach 1932), but fieldwork since 1988 suggests that the species's survival in the country is very precarious. It is a Category One protected species, although the legislation is under revision.

Between 1988 and 1997 interviews were conducted in well over 300 villages in and around existing and proposed protected areas as part of planning for the country's protected area network and during subsequent wildlife surveys (e.g. Salter 1993; see also Evans and Timmins 1996, Davidson et al. 1997, Evans 1997, Tizard et al. 1997). Villagers were asked whether Green Peafowl were present within half a day's walk of the village. These interviews were considered an efficient way of determining the broad distribution of peafowl, since the species is large, conspicuous and familiar to villagers. General wildlife surveys, mainly of proposed pro- 


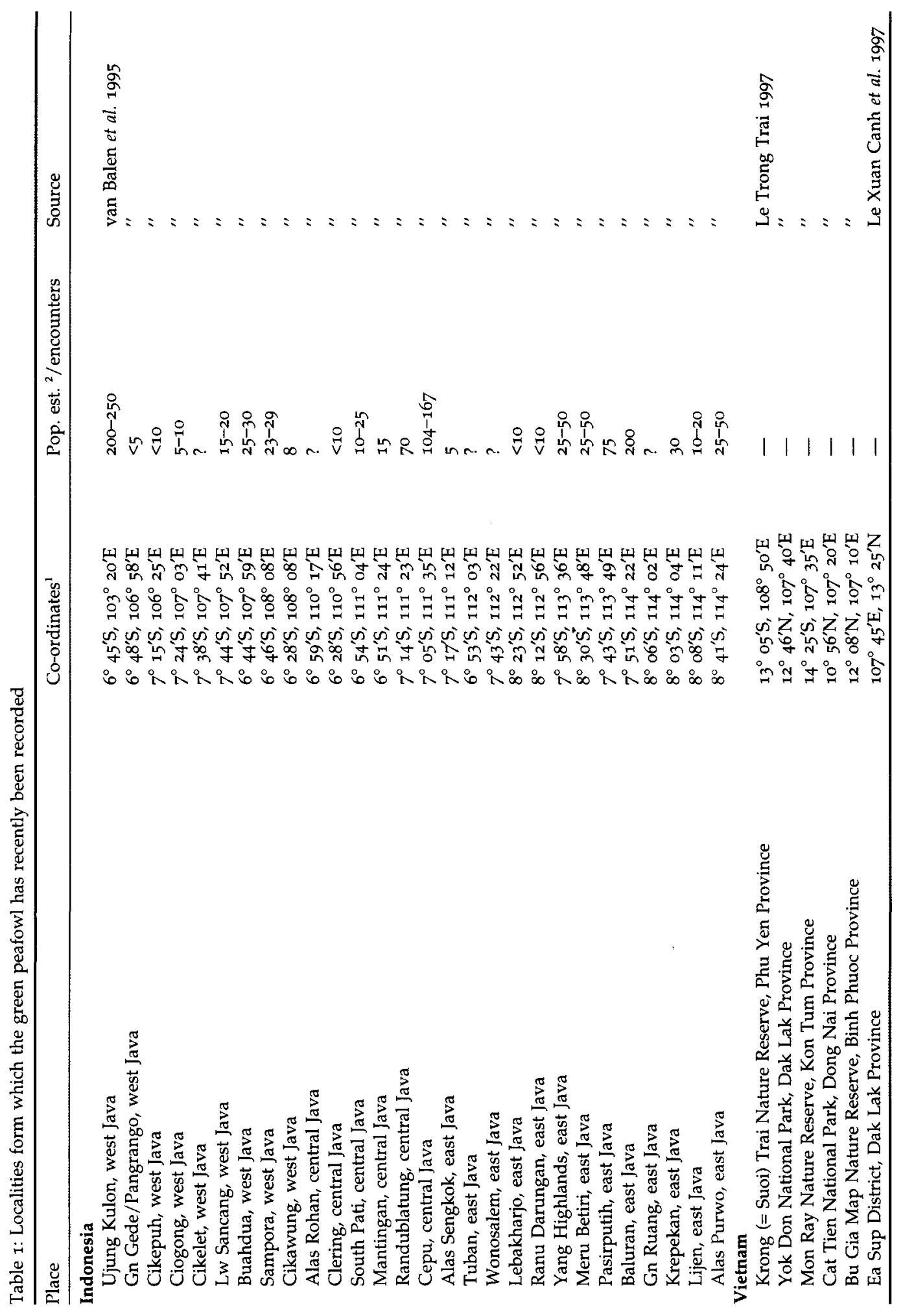




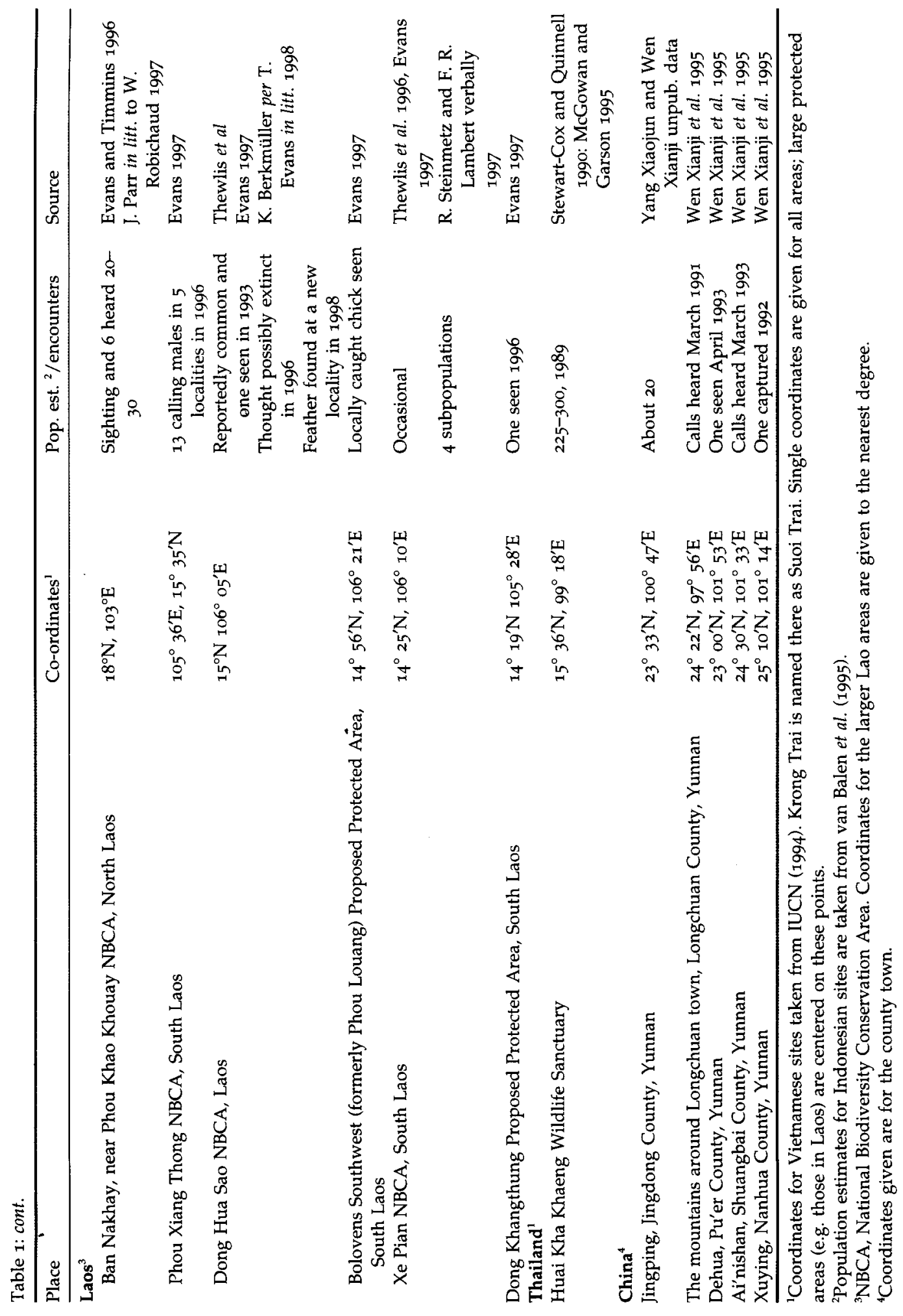




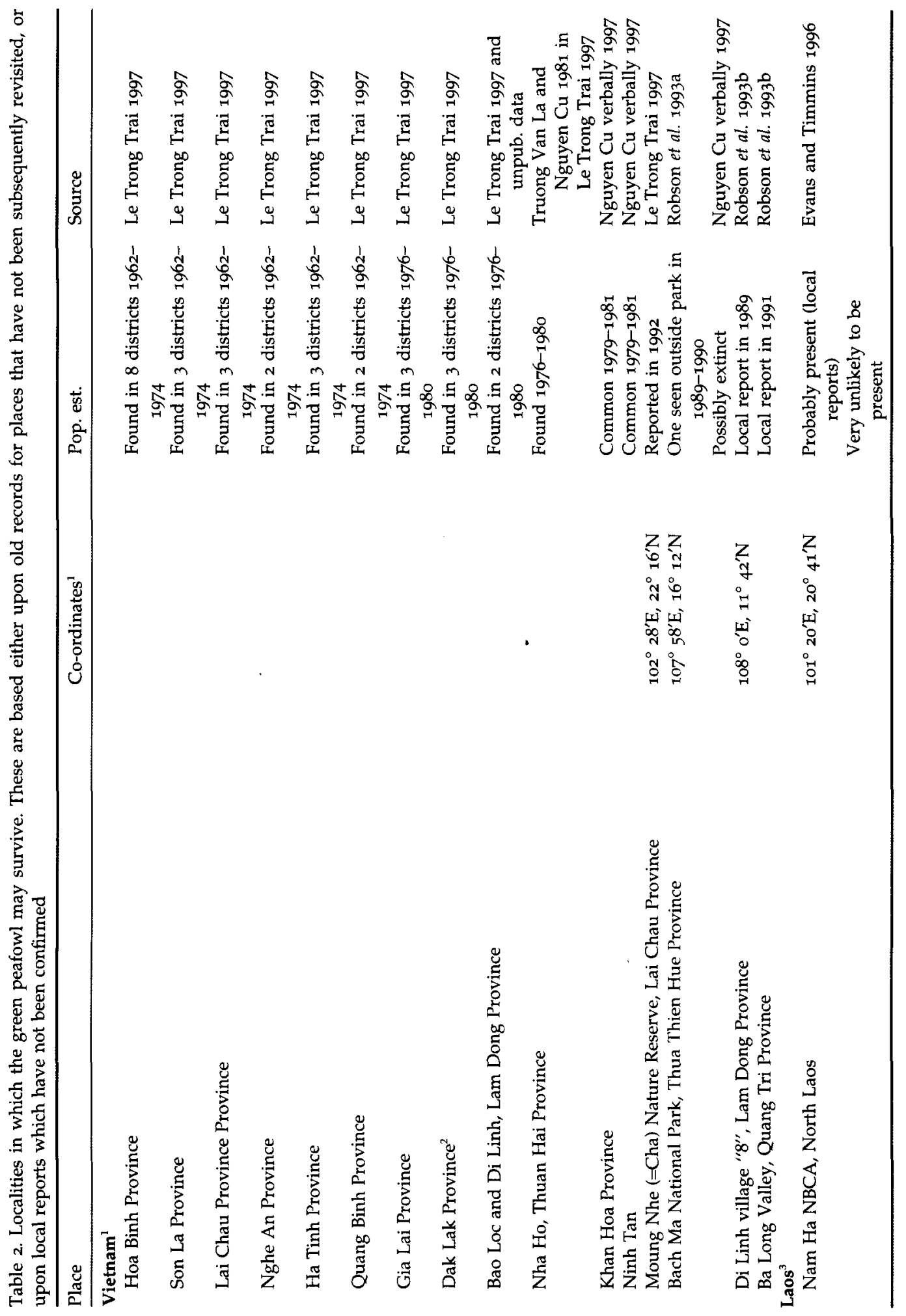




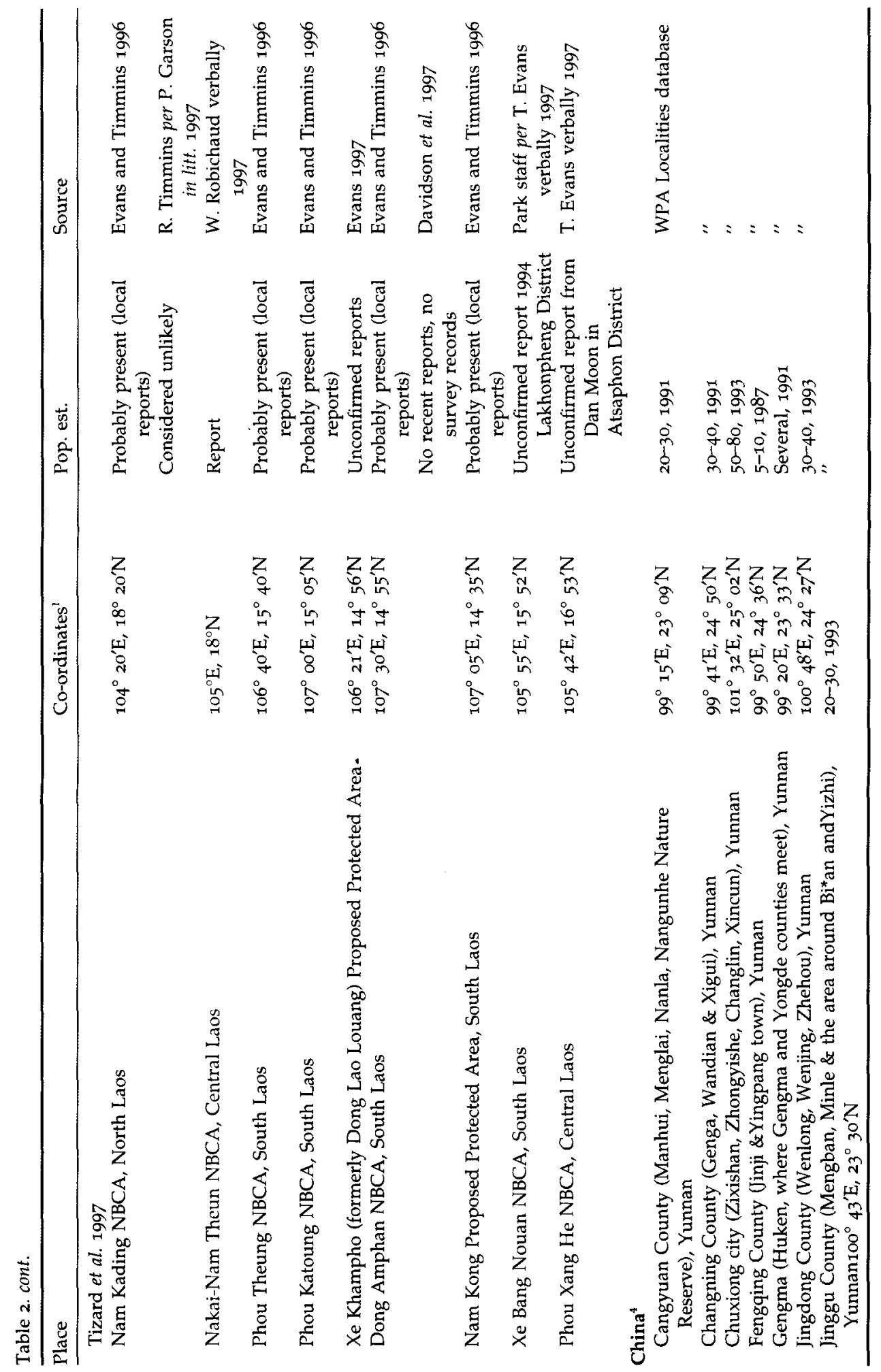




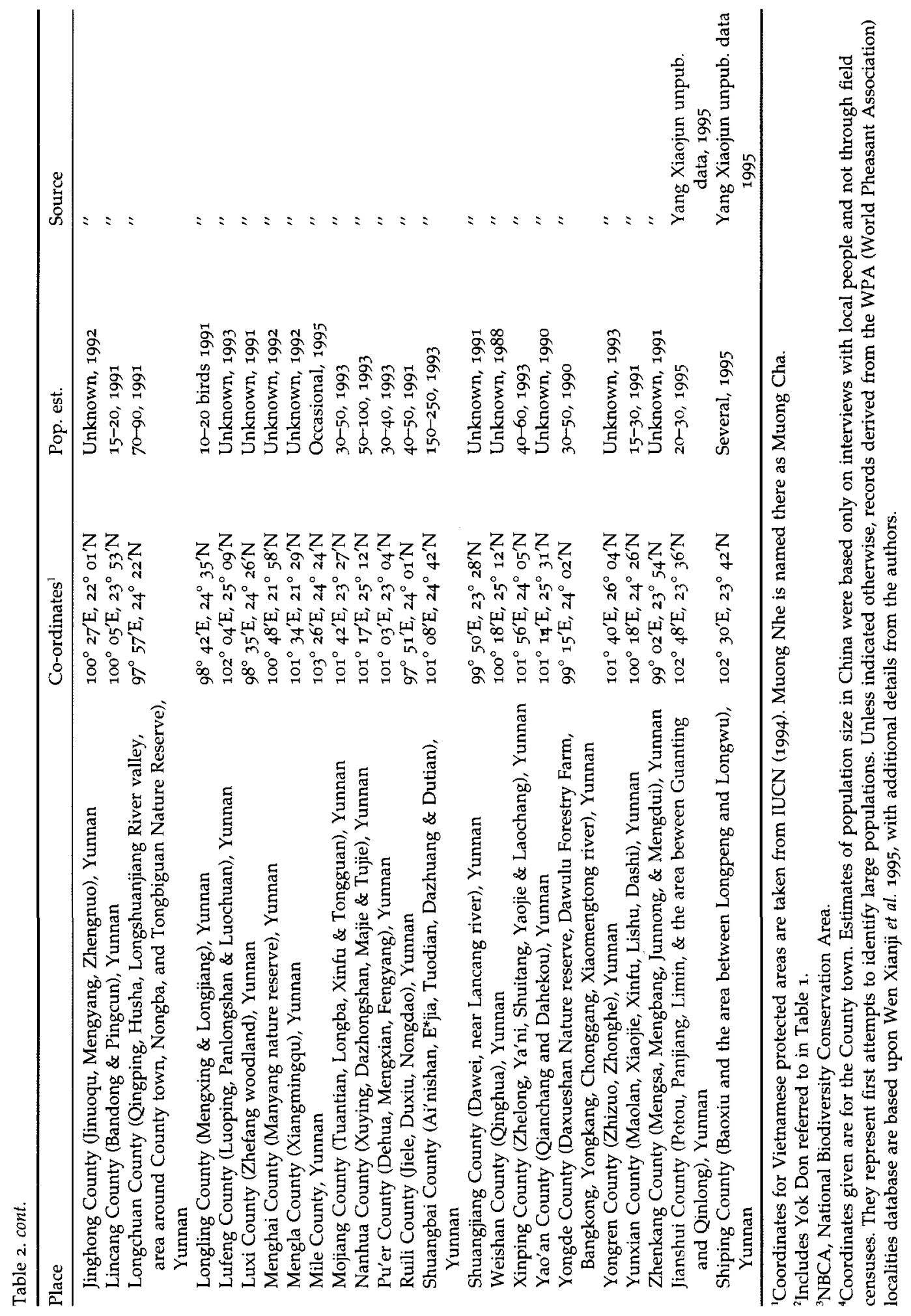


tected areas (most of which have now been declared) were carried out from 1992. Although the Green Peafowl was not the sole target of field surveys, it was one of few species given special attention (Evans and Timmins 1996).

There are six areas with confirmed surviving populations (Table 1) and 10 more sites with unconfirmed recent reports (Table 2). Field surveys and repeat interviews in 7 of these 10 unconfirmed sites have failed to detect any peafowl and remaining populations, if any, are likely to be very small (T. Evans in litt. 1998). Confirmed records were all of small populations, suggesting that large numbers survive at very few sites, if at all. The only population estimate is of 20-30 birds in Phou Khou Khouay National Biodiversity Conservation Area (J. Parr per W. Robichaud verbally 1997), although populations in some of the southern protected areas are likely to be larger than this (T. Evans in litt. 1998). Detecting small Green Peafowl populations in the field is difficult and the species was recently reported from three protected areas in which it had been concluded extinct following previous general bird surveys (Phou Xang He and Xe Bang Nouan: both T. Evans verbally 1997) where villagers report very small numbers and Nakai Nam-Theun (W. Robichaud verbally 1997) (Table 2) where a few birds were reported in 1994 (see Table 1).

\section{China}

There are no systematic historical records of the Green Peafowl's distribution in China, although there are historical reports from Zhejiang, Hubei, Sichuan, Yunnan, Guangxi and Guangdong Provinces, and also from south-eastern Qingling Mountains (He Yeheng 1994). The species is thought to have declined substantially since 1900 and is now restricted to Yunnan and possibly Tibet (=Xizang Zizhiqu Autonomous Region)' (Li Xiangtao 1996, Wen Xianji et al. 1995, Yin Binggao and Liu Wulin 1993). The Green Peafowl is known to have become extinct in 11 counties in Yunnan Province and its extent of occurrence (see Species Survival Commission 1994) in China has decreased to $30,000 \mathrm{~km}^{2}$ (Ding Chang-qing verbally 1997). The total Chinese population size has been tentatively suggested at $800-1000$, based on estimates of the number of birds made by villagers in each area where the Green Peafowl is known to survive (Wen Xianji et al. 1995). It is a First Class protected species in China.

Since 1991 fieldwork has sought to determine the current distribution of the species. It has been confirmed from five counties (Table 1) and there are also unconfirmed reports from elsewhere in these five counties and in a further 26 counties (Table 2). All populations are thought to be isolated from each other and most are small. The largest surviving population may be that in Shuangbai County in central Yunnan where 150-250 birds were reported to survive by locals

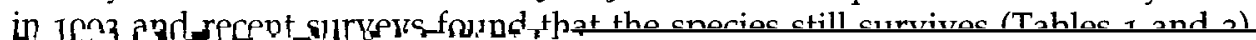


and Nangunhe Nature Reserves) but the population size is thought to be small in all four. It has been reported from two counties in Tibet (Cona and Medog: Yin Binggao and Liu Wulin 1993), but these reports have been questioned by Lhi Zhumei (in McGowan and Garson 1995).

\section{Indonesia}

In Indonesia the Green Peafowl has only ever occurred on Java. Knowledge of the species is perhaps better on this island than elsewhere as historical records have been compiled and detailed surveys carried out in 1990-1991 (van Balen et al. 1995). These surveys found more populations during 1990-1991 than were thought to exist at that time, but most were small and isolated. The two populations estimated to exceed 100 birds were in protected areas: Ujung Kulon and Baluran National Parks. Elsewhere, small populations survived in teak plantations and along the edges between forest and coffee (as well as other plantations), and in smaller nature reserves. There is no information on status to add to van Balen et al. (1995). The species is protected in Indonesia.

\section{Cambodia}

There is little recent information from Cambodia, but the country may well support the largest populations of all, based upon the large areas of suitable habitat with few villages, especially in the east. During 1996 a footprint survey for wild cattle and other very large mammals in two provinces (Mondulkiri and Ratanakiri) in east Cambodia recorded Green Peafowl: they were recorded (direct sightings and indirect evidence) on 7 of 11 field days in Mondulkiri and Ratanakiri (Desai and Lic Vuthy 1996) and two captive (pet) birds were found in Lomphat, a town in Ratanakiri (Duckworth and Hedges in press). A full set of peafowl train feathers was offered to Baird et al. (1996) in Ta Veng District in Ratanakiri from where villagers report a population. A population has also been reported from Phnom Nam Lyr Wildlife Sanctuary in Mondulkiri (Lic Vuthy verbally 1997). The Green Peafowl is also reported from Stung Treng, Preah Vihear, Siem Reap, Pausat (=Pursat), Kampong Speu and Koh Kong Provinces (Lic Vuthy in litt. 1998). It is on the Cambodian list of protected birds.

There was considerable evidence that the species is commonly hunted for meat, feathers and legs in Mondulkiri and Ratanakiri (Desai and Lic Vuthy 1996), despite the fact that hunting is illegal in Cambodia. Martin and Phipps (1996) state that in Cambodia Green Peafowl parts are only used for decoration, although Desai and Lic Vuthy (1996) report that legs are used for medicinal purposes in eastern Cambodia. Legs of Blue Peafowl are used for similar purposes in south India: B. K. Gupta verbally 1997. Tail covert feathers are sold in markets in Phnom Penh and Ban Long and probably elsewhere. In Ban Long, the principal town in Ratanakiri, complete tails were for sale and one shopkeeper said that he exported dead whole birds to Vietnam regularly and he had a stuffed specimen for sale at US\$100 (Martin and Phipps 1996). These may come from populations within the country, although Martin and Phipps did not state unequivocally that the feathers they saw were of the Green, not Blue, Peafowl (see below). 


\section{Myanmar}

There is no recent information on the species in the wild, but 8-10 birds from Myanmar have been held in captivity in private collections and the mini-zoo in Mizoram, north-east India recently. Only one male now survives in the zoo, although it is apparently easy to obtain more birds. Smythies (1986) reported the species as common and widespread, but his observations ceased 50 years ago. In those areas of Myanmar controlled by the Karen National Union, the killing of Green Peafowl is prohibited and the transport of wild animals (except elephants) and their products out of the region is also controlled. These laws are, however, often ineffective because of a lack of commitment (Martin 1997).

\section{Causes for the decline}

Pressures resulting from increased human populations appear to be the main reasons for the decline in numbers of this species, but determining the relative importance of habitat loss and hunting is not easy in most areas. Understanding the role that these pressures play is important if a realistic recovery plan is to be proposed.

\section{Habitat loss}

The species inhabits riverine forest and adjacent open country in much of its range. It has, therefore, been especially susceptible to habitat change as these areas are amongst the first to be cleared and settled by humans (McGowan and Garson 1995). Habitat change has affected many areas in which peafowl were originally found, but it is not known to what degree this has affected Green Peafowl populations. This is because the species may use scrub and other human-modified habitats that, being close to human settlements, are often subject to hunting pressures.

Habitat loss is less of a concern in Laos and Cambodia. In Laos, many areas where villagers report that peafowl have disappeared still retain extensive apparently suitable habitat (e.g. much of Xe Pian and Phou Xang He NBCAs), and in Xe Pian birds visit agricultural land adjacent to natural habitat (R. Steinmetz verbally 1997). This may imply that hunting was the reason for their extirpation. In Cambodia there is still much relatively undisturbed land in the east of the country (Olivier and Woodford 1994, Desai and Lic Vuthy 1996), which is likely to support the species. In Yunnan, China, although peafowl were seen in agricultural land, they were typically not far from forest and most birds were encountered in forest. Although there is little direct evidence, habitat loss was thought the main reason for the decline in areas visited, although villagers have speculated that poisons laid for rodents may be affecting Green Peafowl numbers. This requires confirmation.

\section{Direct exploitation}

For decades at least, the Green Peafowl has been exploited by humans: for food, feathers and eggs (e.g. van Balen et al. 1995). In some cases hunting is likely to 
have played the major role in declining Green Peafowl numbers. For example, although suitable habitat may now be restricted in Peninsular Malaysia, hunting brought about the species's extinction there. In Java, habitat loss seems to have stabilized away from densely populated areas, but it is human desire for the plumage that probably caused the substantial decline in numbers (van Balen et al. 1995). Green Peafowl can survive in teak plantations, but it is not yet known if these populations are self-sustaining.

Currently, birds are hunted for food opportunistically throughout Laos with guns and snares because the meat tastes good and each bird provides a large quantity of meat (Evans and Timmins 1996). Eggs and chicks are also taken to be reared and eaten or sold (T. Evans in litt. 1998). On Java the Green Peafowl is now rarely hunted for food; snared birds are more often sold alive, and eggs that are found are incubated before selling the chicks.

Trade in peafowl train feathers may be a major pressure on many peafowl populations. Before the effects of this activity can be assessed, however, four issues need to be addressed. First, feathers on sale in markets must be identified to species (it is difficult to distinguish between Green and Blue Peafowl train feathers). Second, whether feathers are from wild or captive birds, and whether birds are killed in the process, are both unclear. Third, presence in general wildlife markets provides little information on the origin and destiny because they may receive products from a wide area and distribute them over an equally wide area, and traders are often unable or reluctant to provide exact information ( $T$. Evans in litt. 1998). Fourth, current information, relates only to standing stock and there is no clear idea of the turnover of feathers, etc.

As populations are now typically small, collection of feathers may have a substantial impact if it involves killing wild Green Peafowl. This is suggested by the level of trade in train feathers in three places where train feathers are sought by humans: the Lao-Thai border, Java and China.

On the Lao-Thai border the number of feathers available for purchase was high during visits to the Nong Khai border market between 1992 and 1996 when 5-15 bundles of feathers were seen in each of 10-15 shops (WD and W. Robichaud unpubl. data). Bok Sakon (verbally 1998) found peafowl train feathers widespread in trade along the border in 1997-1998. Train feathers have also been seen for sale at Amphoe Muang, Mukdahan Ror on the border opposite Savannakhet in April 1993 (Srikosamatara and Suthethorn 1994, see also Srikosamatara et al. 1992). For the reasons noted above, the provenance of these feathers is difficult to determine, although in Nong Khai some were probably Blue Peafowl and reported to come from China.

In East Java feathers are the most important element of the traditional reog dance in which $2000-5000$ train feathers are used by one dance company (Mujib 1992). Most existing sets of feathers were destroyed in the 1960s (Soelastri 1995) and are still being replaced by new feathers. Newspaper reports on Java suggest that there are more than rooo dancing groups active in East Java alone. It is not clear whether Blue Peafowl feathers are used at all and it worth noting that between two and three million Blue Peafowl feathers were exported legally from Delhi Airport alone in each of the four years immediately preceding the complete ban on export from India in 1990 (Ahmed 1997). A 1992 newspaper report (Mujib 1992) said that feathers were indeed imported to meet the high demand, but 
Edwin (1988) stated that Blue Peafowl feathers are not wanted and wild Green Peafowl are most sought after (although how this could be determined when handed a bundle of feathers is not clear). Throughout the island train feathers are also used to make souvenirs, either in ear rings which are sold locally near Green Peafowl sites, or as bundles to be put in vases.

In China there is a large market for feathers for decorative purposes, mainly in Yunnan and around Beijing. In Yunnan train feathers are sold in bundles in Kunming and in the towns close to the Myanmar and Laos borders.

Everywhere, the feathers that are sold are in good condition and are rarely, if ever, damaged, abraded or cut at the base. Some naturally moulted feathers do appear in very good condition and so it is not clear whether the feathers are picked up off the ground or are taken from live birds. Feathers are sold in bundles or in some cases in arranged whole trains (e.g. in China).

\section{Future actions}

The Green Peafowl was considered one of the highest conservation action priorities by the Pheasant Specialist Group of the World Pheasant Association, Species Survival Commission and BirdLife International for the period 1995-1999 (McGowan and Garson 1995) and the current review shows this to be well founded. However, formulating a recovery plan is hampered by the fragmented nature of remaining populations throughout such a wide distribution, and the differing levels of knowledge for each range country. Nonetheless, recent status assessments, albeit preliminary in some cases, are sufficient to attempt a coordinated approach to the conservation of this species throughout its range. Actions in the recovery plan fall into four categories:

- strategic review

- assessing status and ecology

- understanding the human-Green Peafowl relationship

- considering the possibility of reintroduction.

\section{Strategic review}

This is concerned with providing the details of the species's decline, identifying conservation actions that may safeguard populations and supporting individuals working to prevent the species's extinction.

(i) Document extinctions and their reasons in order to (a) assess the suitability of areas for potential reintroductions (e.g. Peninsular Malaysia) and (b) to try and ensure that other populations do not also become extinct (e.g. Yunnan, China and the surviving populations in Laos and Vietnam).

(ii) Key protected areas should be safeguarded to assure survival of at least some populations. Two protected areas might be identified for each of Indonesia, Laos and Vietnam on the basis of population size and the likelihood of long-term survival, the latter influenced by the level of active management. In China, very few Green Peafowl have been recorded from protected areas and so the establishment of new reserves is urged. We suggest that the following sites be recognized as instrumental in the long-term survival of the Green Peafowl: 
- Vietnam: Yok Don National Park and the adjacent unprotected area of Ea Sup District; Cat Tien National Park;

- Laos: Phou Khao Khouay and Xe Pian National Biodiversity Conservation Areas and Dong Khanthung Proposed Protected Area;

- Indonesia: Ujung Kulon and Baluran National Parks;

- Thailand: Huai Kha Khaeng Wildlife Sanctuary (and World Heritage Site);

- China: the largest populations are believed to be (a) where Shuangbai County, Chuxiong City and Lufeng County all meet, (b) the range including Lishejiang River, Malonghe River, and Taihejiang River in Chuxiong City, Nanhua County, Shuangbai County and Xinping County.

- Myanmar: to be identified

- Cambodia: presently it is not possible to identify key sites and, indeed, this may be inappropriate as the species is still likely to be reasonably widespread.

The main threats to these sites should be documented and ways in which these issues might be addressed should be determined.

(iii) Maintain a network of key interested people under the auspices of the Pheasant Specialist Group.

(iv) Establish contact with existing conservation initiatives that may benefit the Green Peafowl so that the plight of the species and the need for action on its behalf are fully understood. For example, Phou Khao Khouay National Biodiversity Conservation Area (near Vientiane, Laos) is the subject of an Asian Development Bank-funded two-year project to establish effective management for the area and to minimize the effects of a hydroelectric power project. The latter will not impact directly on the area occupied by peafowl, but the increased development and human presence are likely to result in greatly increased hunting rates and market for wildlife curios. At present the extent of the area used by peafowl in Phou Khao Khouay is being mapped as a focal point of this project (J. Parr per W. Robichaud verbally 1997)

\section{Status and ecology}

(i) Further survey work. Myanmar and Cambodia are the highest priorities for further survey. Previous knowledge of status in Myanmar and the amount of habitat believed to remain in eastern Cambodia suggest that these countries hold the largest national populations of the species. However, guns are plentiful in Cambodia and hunting may be extensive. Additional surveys in unsearched areas of southern Vietnam are also of high priority. Knowledge of distributions in China, southern Laos and Indonesia can obviously be improved, but more intensive studies may be the priorities in those countries now.

(ii) Understanding the species's ecology is clearly necessary to understand its habitat requirements and thus its response to habitat alteration. Knowledge of social structure and calling behaviour would help interpret results from surveys into meaningful population estimates. This should involve one, possibly two, intensive studies (probably Java and Laos or Yunnan) that would attempt to identify patterns of habitat use. Limiting factors should be determined. These 
might include habitat-related features such as whether roosting trees are limiting and how suitable are teak plantations, and demographic features such as reproductive rate, sex ratio and dispersal needs. Work on producing a meaningful survey technique would clearly have benefits in allowing surveys to be efficiently designed and their results interpreted reliably.

\section{Human-peafowl relationship}

The Green Peafowl plays a prominent role in local human culture in several areas. It would be valuable to understand the importance of this relationship in particular communities and its impact on peafowl populations. In particular, trade in train feathers is clearly important in some areas, but it is unclear whether this trade drains wild populations or is neutral to the species's survival prospects in the wild (see above). Nor is it known whether it is important to local economies. An attempt should be made to quantitatively describe the trade (both sources and markets) in areas around one or more of the key sites identified above.

This should also address the desirability of meeting the demand for feathers by establishing Green Peafowl farms or by importing Blue Peafowl feathers. It is important that no Blue Peafowl should be farmed within the range of the Green Peafowl because the species do hydridize (Delacour 1977). There may be ways in which this close relationship between humans and the Green Peafowl can advance conservation of the species and the feasibility of an awareness programme centred on local attachments to the species (where they exist) should be investigated, whilst taking care not to stimulate demand for birds.

\section{Reintroduction}

The species is extinct in Peninsular Malaysia and there is a national desire to re-establish a population. However, the likelihood of success will be increased if reintroduction is attempted only when the reasons for extinction are no longer operating and suitable stock for reintroduction and appropriate habitat have been identified. All stages should be conducted in accordance with IUCN guidelines for reintroduction (IUCN 1998).

Understanding the causes of extinction should involve both structured interviews and literature research. It is popularly believed that hunting was the main cause, but whether other factors may have contributed requires assessment. Identification of a suitable reintroduction site should be based upon the habitat the species occupied in the peninsula, habitat use limits in other countries and today's distribution of potential blocks of habitat. Final selection should be based upon habitat suitability and extent, and the potential for ensuring the protection of the species.

The identification of suitable stock should follow IUCN reintroduction guidelines. Issues that should be addressed are:

- the racial and geographical origin of the birds;

- whether translocated wild stock or released captive birds would be most appropriate. 


\section{Acknowledgments}

Many agencies have funded the work reviewed here which was conducted with the support of many colleagues and local people. There are far too many to mention here, but all have been acknowledged in the papers and reports cited. We are also grateful to the many colleagues who have provided unpublished information and who are mentioned throughout the paper. This paper resulted from a workshop at the International Galliformes Symposium in Malaysia during 1997 and we gladly acknowledge the invaluable financial support of the World Pheasant Association, which allowed several participants to attend, and the arrangements for the workshop made by the Department of Wildlife and National Parks, Peninsular Malaysia. Zhang Zheng-wang and Ding Chang-qing provided valuable input at the workshop and subsequently and John Carroll, Tom Evans and Simon Hedges kindly reviewed the manuscript and made considerable improvements to it. Tom Evans and Colin Poole also generously added valuable up-to-date information.

\section{References}

Ahmed, A. (1997) Live bird trade in northern India. Delhi: TRAFFIC-India.

Baird, 1. G., Kaneungnit Tubtim and Baird, M. (1996) The Kavet and the Kreung. Observations of livelihoods and natural resources in two highlander villages in the districts of Veun Say and Ta Veng, Ratanakiri Province, Cambodia. Livelihoods and natural resources study. U.K. and Ireland: Novib and Oxfam

Beebe, W. (1922) Monograph of the pheasants, IV. New York: Reprinted by Dover Publications, 1990.

Choudhury, A. (1992) Wildlife in Manipur: a preliminary survey. Tiger Paper 19(1): 20-28.

Davidson, P., Robichaud, W. G., Tizard, R. J., Vongkhamheng, C. and Wolstencroft, J. (1997) A wildlife and habitat survey of Dong Ampham NBCA and Phou Khatong proposed NBCA, Attapu Province, Lao PDR. Vientiane: The Wildlife Conservation Society.

Davison, G. W. H. and Scriven, K. (1987) Recent pheasant surveys in Peninsular Malaysia. Pp. 90-101 in C. D. W. Savage and M. W. Ridley, eds. Pheasants in Asia 1982. Reading, U.K.: World Pheasant Association.

Delacour, J. (1929) On the birds collected during the fourth expedition to French Indochina. Ibis 12: 193-220, 403-429.

Delacour, J. (1977) Pheasants of the world. Second edition. Hindhead, U.K.: Spur Publications.

Desai, A. A. and Lic Vuthy (1996) Status and distribution of large mammals in eastern Cambodia. Phnom Penh, Cambodia: IUCN/FFI/WWF Large Mammal Conservation Project.

Duckworth, J. W. and Hedges, S. (in press) Bird records from Cambodia in 1997, including 16 species new for the country. Forktail 14 .

Edwin, N. (1988) The Reog Ponorogo: conflict between nature and tradition. Voice of Nature 58: 28-34.

Engelbach, P. (1932) Les oiseaux de Laos meridional. L'Oiseau R.f.o 2: 439-498.

Evans, T. (1997) Green Peafowl Pavo muticus in Laos. Tragopan 6: 9-10.

Evans, T. D. and Timmins, R. J. (1996) The status of Green Peafowl Pavo muticus in Laos. Forktail 11: 11-32.

Harvey, W. G. (1990) Birds in Bangladesh. Dhaka, Bangladesh: The University Press.

He Yeheng (1994) The historical shifts of rare birds in China. Changsha, Hunan, China: Hunan Scientific and Technological Publishing House. 
IUCN (1994) The 1993 United Nations list of national parks and protected areas. Gland, Switzerland: IUCN.

IUCN (1998) Guidelines for Reintroductions. Prepared by the IUCN/SSC Reintroduction Specialist Group, IUCN: Gland, Switzerland and Cambridge, U.K.

Le Trong Trai (1997) Historical and current distribution of Green Peafowl in Vietnam. Tragopan 7: 16-17.

Le Xuan Canh, Pham Trong Anh, Duckworth, J. W., Vu Ngoc Thanh and Lic Vuthy (1997) A survey of large mammals in Dak Lak Province, Vietnam. Hanoi, Vietnam: WWF/IUCN.

Li Xiangtao (1996) The gamebirds of China: their distribution and status. Beijing, China: International Academic Publishers.

McGowan, P. J. K. and Garson, P. J. (1995) Pheasants: status survey and conservation action plan 1995-1999. Gland, Switzerland: IUCN.

Martin, E. B. (1997) Wildlife products for sale in Myanmar. TRAFFIC Bull. 17: 33-44.

Martin, E. B. and Phipps, M. (1996) A review of wild animal trade in Cambodia. TRAFFIC Bull. 16: 45-6o.

Medway, Lord and Wells, D. R. (1976) The birds of the Malay Peninsula, London and Kuala Lumpur: Witherby and Universiti Malaya.

Mujib (1992) [Imported peafowl feathers]. Jawa Pos 20 January 1992: 12. (In Indonesian).

Nguyen $\mathrm{Cu}, \mathrm{N}$. and Eames, J. (1993) The distribution and status of pheasants in Vietnam. Pp. 20-27 in D. Jenkins, ed., Pheasants in Asia 1992. Reading, U.K.: World Pheasant Association.

Olivier, R. and Woodford, M. 1994. Aerial surveys for Kouprey in Cambodia, March 1994. Gland, Switzerland and Cambridge, U.K.: IUCN.

Robson, C. R., Eames, J. C., Newman, M., Nguyen Cu, Truong Van La (1991) Forest bird surveys in Vietnam 1989/1990: final report. Unpublished report to the International Council for Bird Preservation.

Robson, C. R., Eames, J. C., Nguyen Cu and Truong Van La (1993a) Further records of birds from Viet Nam. Forktail 8: 25-52.

Robson, C. R., Eames, J. C., Nguyen.Cu and Truong Van La (1993b) Birds recorded during the third BirdLife/Forest Birds Working Group expedition to Viet Nam. Forktail 9: 89119.

Round, P. D. (1988) Resident forest birds of Thailand: their status and conservation. Cambridge, U.K.: International Council for Bird Preservation.

Salter, R. E. (1993) Wildlife in Lao PDR: a status report. Vientiane: IUCN.

Smythies, B. E. (1986) The birds of Burma. Liss, Hampshire and Pickering, Ontario: Nimrod Press and Silvio Mattacchione.

Soelastri (1995) [Reog Ponorogo, the never dying folk art]. Kompas 18 June 1995: 15. (In Indonesian).

Species Survival Commission (1994) IUCN Red List categories. Gland, Switzerland: IUCN. Srikosamatara, S. and Suthethorn, V. (1994) Wildlife conservation along the Thai-Lao Border. Nat. Hist. Bull. Siam Soc. 42: 3-21.

Srikosamatara, S. Siripoldej, B. and Suthethorn, V. (1992) Wildlife trade in Lao PDR and between Lao PDR and Thailand. Nat. Hist. Bull. Siam Soc. 41: 1-47.

Stewart-Cox, B. (1997) Thailand's expanding Green Peafowl population. Oryx 31: 10.

Stewart-Cox, B. and Quinnell, R. (1990) Using calls, footprints and sightings to survey Green Peafowl in western Thailand. Pp. 129-137 in D. A. Hill, P. J. Garson and D. Jenkins, eds., Pheasants in Asia 1989. Reading, U.K.: World Pheasant Association.

Thewlis, R. M., Timmins, R. J., Evans, T. D. and Duckworth, J. W. (in press) The conservation status of birds in Laos: a review of key species. Bird Conserv. Intern.

Tizard, R., Davidson, P., Khounboline, K. and Salivong, K. (1997) A wildlife and habitat survey of Nam Ha and Nam Kong Protected Areas, Luang Namtha Province, Lao PDR. Vientiane: The Wildlife Society. 
van Balen, S., Prawiradilaga, D. M, and Indrawan, M. (1995) The distribution and status of Green Peafowl in Java. Biol. Conserv. 71: 289-297.

Wen Xianji, Yang Xiaojun, Han Lianxian, Yang Lan and Wang Weimin (1995) Investigations on the current status of Green Peafowl in China. Chinese Biodivers. 3: 46-51. (In Chinese, English summary).

Yin Binggao and Liu Wulin (ed.). (1993) Wildlife protection in Tibet. Beijing, China: China Forestry Publishing House.

\section{P. MCGOWAN}

Ecoscope Applied Ecologists, 9, Bennell Court, Comberton, Cambridge CB3 7 DS, U.K.

\section{J. W. DUCKWORTH}

BirdLife International Vietnam Programme, 293 B Tay Son, Dong Da, Hanoi, Vietnam (current postal address: c/o East Redham Farm, Pilning, Bristol, BS 35 4JG, U.K.)

\section{WEN XIANJI}

Kunming Institute of Zoology, Academia Sinica, Kunming, Yunnan 650223, China

\section{B. VAN BALEN}

BirdLife International - Indonesia Programme, Jln. Jend. A. Yani 11, PO Box 310/Boo, Bogor 16003, Indonesia (current address: Tropical Nature Conservation \& Vertebrate Ecology, Department Environmental Sciences, Wageningen Agricultural University, Bornsesteeg 69, 6708 PD Wageningen, The Netherlands)

\section{YANG XIAOJUN}

Kunming Institute of Zoology, Academia Sinica, Kunming, Yunnan 650223, China

\section{MOHD. KHAN MOMIN KHAN}

No. 10, Jalan Bomoh, off Jalan Keramat Huyong, 5610o Kuala Lumpur, Malaysia

\section{SITI HAWA YATIM}

Department of Wildlife and National Parks of Peninsular (PERHILITAN), Km. 10 Jalan Cheras, Kuala Lumpur 50664, Malaysia

\section{LALRAM THANGA}

DCF (Headquarters), Department of Environment and Forests, Government of Mizoram, Tuikhuahtlang, Aizawl, Mizoram 796991, India

\section{IWAN SETIAWAN}

BirdLife International - Indonesia Programme, Jln. Jend. A Yani 11, PO Box 310/Boo, Bogor 16003, Indonesia.

\section{RAHUL KAUL}

World Pheasant Association - South Asia Regional Office, WWF-India Secretariat, 172-B Lodi Estate, New Delhi 110 023, India 